\title{
SKIL wt Allele
}

National Cancer Institute

\section{Source}

National Cancer Institute. SKIL wt Allele. NCI Thesaurus. Code C52240.

Human SKIL wild-type allele is located in the vicinity of $3 \mathrm{q} 26$ and is approximately $35 \mathrm{~kb}$ in length. This allele, which encodes Ski-like protein, plays a role in transcriptional modulation of transforming growth factor-beta stimulated genes. 